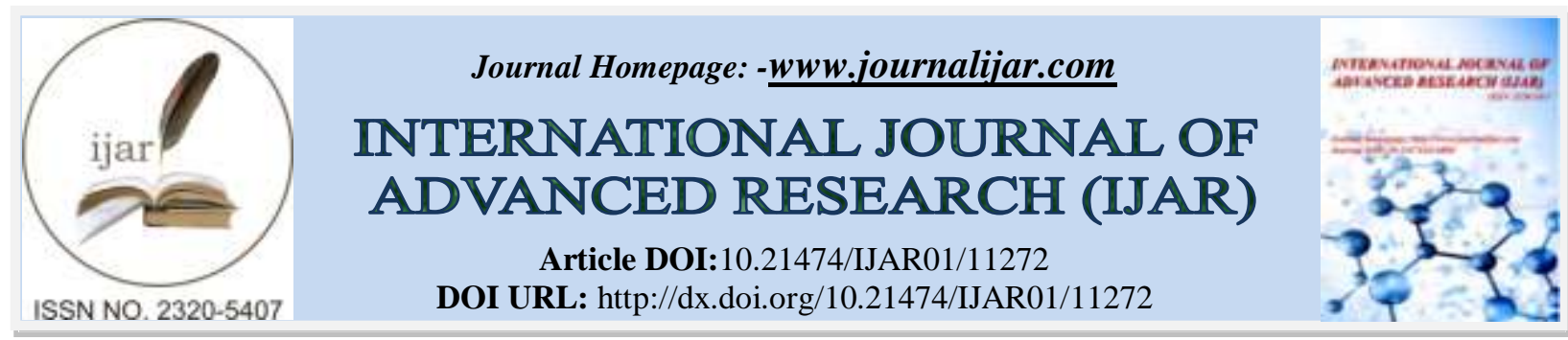

RESEARCH ARTICLE

\title{
DIVERSITY AND TRADITIONAL KNOWLEDGE OF SOME WILD EDIBLE FRUITS USED BY RURAL COMMUNITIES OF DISTRICT MANDI, HIMACHAL PRADESH
}

\author{
Sharma Ritu ${ }^{1}$, Goraya G.S. ${ }^{2}$ and Seth M.K ${ }^{3}$ \\ 1. Ph.D. Research Scholar, Department of Biosciences, Himachal Pradesh University, Shimla-5. \\ 2. Principal Chief Conservator of Forests (Retd.), Himachal Pradesh Forest Department, India. \\ 3. Professor (Retd.) and Guest Teaching Faculty, Department of Biosciences, Himachal Pradesh University, \\ Shimla-5.
}

\section{Manuscript Info}

\section{Manuscript History}

Received: 05 May 2020

Final Accepted: 10 June 2020

Published: July 2020

Key words:-

Wild Fruits, Biodiversity, Medicinal,

Traditional Knowledge, Mandi,

Himachal Pradesh

\begin{abstract}
Wild fruits have a significant role in giving sustenance and are rich source of nutrition. Regardless of their therapeutic potential, they are the source of carbohydrates, proteins, vitamins, minerals and fiber. The best thing about the wild fruits is that they are simply natural and accessible during their season only. That is the reason the wild fruits are eaten as a major aspect of convention and are profoundly valued and sought after. The present study reveals the ethnobotanical exploration, identification and future potentialities of the wild edible fruits consumed by the folklore of Mandi district. Twenty species belonging to sixteen genera and twelve families, Rosaceae being dominant are reported. These wild fruits contain unique medicinal properties and certain phytochemicals and are used traditionally to cure various ailments like cough, fever, diabetes, weakness, indigestion and so on. These wild resources demand stipulated attention for their conservation and management. The utilization of these wild resources in commercial food products can improve their nutritional value and can open the scopes for the development of neutraceuticals.
\end{abstract}

Copy Right, IJAR, 2020,. All rights reserved.

\section{Introduction:-}

Wild plants are an integral part of the diet of humans since most primitive civilizations. Consuming wild edibles is part of the food habits of people in many societies and intimately connected to virtually all aspects of their sociocultural, spiritual life and health (Singh A,2006). Our ancestors selected some wild species over others for their unique attributes and chose the ones which fit into their needs in daily life like food, medicine, fuel, fodder, agricultural tools, furniture and house building and other purposes. These wild plants have proven their ability as supplementary food during scarcity periods and cure against minor ailments in the times of human history. Himachal Pradesh, a hilly state in the North Western Himalaya is rich in its biological diversity and about $90 \%$ population reside in the rural areas (Census, 2011). Most rural people are dependent on the forests and their products to meet their daily requirements. Collection of fruits from forests is an age old practice in the State and is still prevailing as a routine and culture among folklores. The wild fruits are either consumed raw or cooked and in the form of processed products like pickles, jams, juices and Chutney. These wild fruits are not only the source of carbohydrates, proteins, vitamins and fiber but have unique medicinal properties as well. Many households in the State are dependent upon the wild fruits for their income as well. Some wild fruits have magico religious significance as well. The fruit 
collected from the wild are purely natural, free from chemicals, has low sugar level and are enriched with many phytochemicals and antioxidants. Moreover, these species flourish in their natural habitats and are exposed to different unfavourable conditions in this manner are relied upon to have strength against different biotic and abiotic stresses. Assessment of these hereditary assets for the recognizable proof of qualities for natural product quality, hardiness, resistance against ailments and pests, soil factors and so forth will serve as a database for future purpose.

\section{Review of Literature:-}

Various researchers have done work on the utilization of edible wild species around the globe. There are about 1532 wild edible food species in India out of which 675 species are found in the Himalayan region (Kala CP, 2007; Reddy et al, 2007; Samant \& Dhar, 1997). Nutritional value of some wild food plants and their role in tribal nutrition was documented by Maikhuri (Maikhuri RK, 1991). Several wild edible fruits are documented from Uttarakhand (Arya D, 2013; Kanchan et al, 2010; Kala CP, 2007; Rawat et al, 1994; Gaur RD, 1977). In Himachal Pradesh, several researchers have explored many wild edibles. Brij et al (1996) described the plants used as supplement food by Gaddis. N.S. Chauhan (1999) described medicinal and aromatic plants of Himachal Pradesh. Singh (1999) enumerated some useful plants of Kullu district. Edgeworth and William Hawtanye Parish: First time collected plants from Mandi in the first half of $19^{\text {th }}$ Century (Burkhill, 1965). Murti \& Uniyal (1985), Rawat \& Srivastva (1986), Marpa \& Samant (2012), Sharma et al (2015) reported some plants from District Mandi. Singh P.B. (1993, 1994, 1996, 1997, 2018) enumerated Flora of the District Mandi in details but with little emphasis on utilizations. Sharma, P., Agnihotry, A., Sharma, P. P., \& Sharma, L. (2013) documented wild edibles of Murari Devi and surrounding areas in Mandi district. Singh P.B. (1996) has documented some wild edible plants of Mandi district in Northwest Himalaya. Sood S.K. and Thakur S. (2004) did ethnobotanical documentation of Rewalsar. Traditional uses of ethnomedicinal plants of lower foot-hills of Himachal Pradesh was documented by Parkash, V., \& Aggarwal, A. (2010). Kaur et al. (2011) studied the uses of plants in controlling the different diseases in Mandi district (H.P). Ethnobotanical Uses of Some Medicinal Plants of District Mandi were documented by Kumar S. (2015). Seth M.K. \& Sharma R. (2020) described the role of rural women and their role in plant conservation in District Mandi. However the study with the main emphasis on wild fruits along with their medicinal, ritualistic and other important aspects has not been done from Mandi District yet.

\section{Study Area:}

Mandi district is situated between $31^{\circ} 72^{\prime} \mathrm{N}$ latitude and $76^{\circ} 92^{\prime} \mathrm{E}$ longitude and covers a geographical area of 3950 $\mathrm{km}^{2}$. It is bounded by Kangra district in the North and North West, Hamirpur and Bilaspur district in the West and by Kullu district in the East. It occupies second rank among the twelve districts in the population rate. The altitude varies between 503 meter and 4034 meter asl. District Mandi is sorrounded by Dhauladhar, Ghogardhar, Sikandar Dhar and Vairkot Dhar. Beas and Sutlej are major rivers in the District. The district receives an ample and uniformly distributed rainfall.

\section{Material and Methods:-}

Different methods were adopted for ethnobotanical data collection. Surveys were conducted in the district from 2015-2018. A free list technique was used to get information about the knowledge of wild edible fruit species from informants who proved very helpful to get information from illiterate people. Formal questionnaire was also framed to get more information from informants. All plant species were arranged alphabetically which included botanical name, family, vernacular name, habit and their utilizations. The plants were identified with the help of existing standard literature available on the flora of the region [Flora Simlensis, (Collett, 1902); Flowers of Himalaya, (Polunin O. \& Stainton A,1997); Flora of District Mandi, North West Himalaya (Singh PB, 2018)].

\section{Results and Discussions:-}

In present study it was found that fruits of 20 species belonging to 14 genera and 12 families are in use by the folklore of Mandi district in Western Himalaya, Himachal Pradesh (Table-1). Photographs of some of plants have been provided. These wild fruits are not the only source of nutrition and food but also serve the multipurpose role such as medicine, fodder, fuel, agriculture, tools, fencing and ritualistic aspects. It was found that apart from used as edible fruit 8 plants species are used as fodder, 15 as fuelwood, 9 species have high medicinal potential, 4 species have socio religious aspect. In addition to that, 12 species are source of income and 5 species are processed in the form of Jams, chutneys, pickles (Fig 3). The most frequently used wild fruits are from family Rosaceae. Distribution of plant according to their habit it was recorded that tree species were markedly high (14) followed by 
shrubs (05), herbs (01) (Fig-2). Majority of these fruits are available from mid of summer to end of the rainy seasons.

Table 1:- Table showing list of Wild Edible Fruits along with their Folk Uses.

\begin{tabular}{|c|c|c|c|c|c|c|}
\hline $\begin{array}{l}\text { Sr. } \\
\text { No. }\end{array}$ & Botanical Name & $\begin{array}{l}\text { Vernacular } \\
\text { Name }\end{array}$ & Family & Habit & $\begin{array}{l}\text { Flowering- } \\
\text { Fruiting }\end{array}$ & Folk Uses \\
\hline 1 & $\begin{array}{l}\text { Aegle marmelos } \\
\text { (L.) Correa }\end{array}$ & Bilva, Bel & Rutaceae & Tree & Mar- Aug & $\begin{array}{l}\text { Eaten ripened; given to cure } \\
\text { constipation. Leaves offered to } \\
\text { Lord Shiva. }\end{array}$ \\
\hline 2 & $\begin{array}{l}\text { Berberis aristata } \\
\text { DC. }\end{array}$ & $\begin{array}{l}\text { Kashmal, } \\
\text { Darhaldi }\end{array}$ & Berberidaceae & Shrub & May- Sep. & $\begin{array}{l}\text { Eaten ripened, balances sugar } \\
\text { level, appetizer. Roots used to } \\
\text { cure eye disorder. Used for } \\
\text { Fencing. }\end{array}$ \\
\hline 3 & 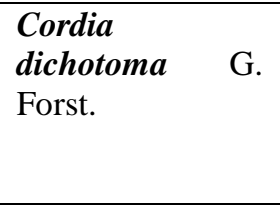 & Lasoore & Moraceae & Tree & April-July & $\begin{array}{l}\text { Eaten ripened, unripened fruits } \\
\text { are cooked as vegetable. } \\
\text { Leaves used as fodder. Wood } \\
\text { used as fuelwood, used to } \\
\text { make agricultural tools. }\end{array}$ \\
\hline 4 & $\begin{array}{l}\text { Cornus capitata } \\
\text { Wall. }\end{array}$ & Guldhara & Cornaceae & Tree & May- July & $\begin{array}{l}\text { Eaten ripened. Wood used as } \\
\text { fuelwood, used to make } \\
\text { agricultural tools. }\end{array}$ \\
\hline 5 & $\begin{array}{l}\text { Duschesnea } \\
\text { indica (Andr.) } \\
\text { Focke }\end{array}$ & $\begin{array}{l}\text { Bhumi } \\
\text { Aakhe }\end{array}$ & Rosaceae & Herb & $\begin{array}{l}\text { March- } \\
\text { July }\end{array}$ & Eaten ripened. \\
\hline 6 & $\begin{array}{l}\text { Elaegnus } \\
\text { parvifolia } \\
\text { Wall.ex Royle }\end{array}$ & Ghain & Elaegnaceae & Shrub & April- June & $\begin{array}{l}\text { Eaten ripened. Used as hedge } \\
\text { plant. }\end{array}$ \\
\hline 7 & $\begin{array}{l}\text { Ficus auriculata } \\
\text { Lour. }\end{array}$ & Trembloo & Moraceae & Tree & May- July & $\begin{array}{l}\text { Eaten ripened. Leaves used as } \\
\text { fodder for increasing milk } \\
\text { yield. }\end{array}$ \\
\hline 8 & $\begin{array}{l}\text { Ficus hispida } \\
\text { L.f. }\end{array}$ & Debre & Moraceae & Tree & May- July & $\begin{array}{l}\text { Eaten ripened. Wood used as } \\
\text { fuelwood. Leaves used as } \\
\text { fodder. }\end{array}$ \\
\hline 9 & $\begin{array}{l}\text { Ficus palmate } \\
\text { Forsk. }\end{array}$ & Phegri & Moraceae & Tree & May- Aug & $\begin{array}{l}\text { Unripe fruits along with tender } \\
\text { leaves cooked as vegetable, } \\
\text { eaten ripened as well. Leaves } \\
\text { used as fodder to enhance milk } \\
\text { yield. Wood used as fuelwood. }\end{array}$ \\
\hline 10 & Juglans regia $\mathrm{L}$. & Khod & Juglandaceae & Tree & Mar- Sep. & $\begin{array}{l}\text { Eaten ripened, also as dry fruit } \\
\text { being of high economic and } \\
\text { medicinal value. Twig used as } \\
\text { toothbrush/ Daatun. Nuts used } \\
\text { during "Sair Poojan". Wood is } \\
\text { used to make furniture. }\end{array}$ \\
\hline 11 & Morus alba L. & Chimu & Moraceae & Tree & Mar- June & $\begin{array}{l}\text { Eaten ripen, processed into } \\
\text { jam; considered digestive, } \\
\text { improve the immune system. } \\
\text { Leaves used as fodder for } \\
\text { cattle and silkworms. Wood } \\
\text { used as fuelwood, furniture, } \\
\text { agricultural tools. }\end{array}$ \\
\hline 12 & $\begin{array}{l}\text { Myrica } \\
\text { esculenta } \\
\text { Buch.Ham }\end{array}$ & Kaaphal & Myricaceae & Tree & Oct- June & $\begin{array}{l}\text { Eaten ripen. Cure indigestion, } \\
\text { breathing problems, urinary } \\
\text { problems. Bark decoction is }\end{array}$ \\
\hline
\end{tabular}




\begin{tabular}{|c|c|c|c|c|c|c|}
\hline & D.Don & & & & & $\begin{array}{l}\text { given in asthma, fever. Leaves } \\
\text { used as fodder for enhancing } \\
\text { milk yield. }\end{array}$ \\
\hline 13 & $\begin{array}{l}\text { Phyllanthus } \\
\text { emblica L. }\end{array}$ & Amla, Aonla & Euphorbiaceae & Tree & Mar- Nov & $\begin{array}{l}\text { Eaten raw; processed into } \\
\text { pickles, murraba, juice. High } \\
\text { medicinal potential, cures } \\
\text { digestive system, hair tonic, } \\
\text { one of the ingredient of } \\
\text { "Triphala", improves } \\
\text { immunity. Used as altar in } \\
\text { "Tulsi Vivah". }\end{array}$ \\
\hline 14 & $\begin{array}{l}\text { Prinsepia utilis } \\
\text { Royle }\end{array}$ & Bhekhal & Rosaceae & Shrub & Dec.- July & $\begin{array}{l}\text { Eaten ripened. Seeds are } \\
\text { expressed and seed oil is used } \\
\text { to relieve muscular pains. } \\
\text { Twigs are put on hair by } \\
\text { women while carrying their } \\
\text { little kids during visit to forests } \\
\text { to keep them protected against } \\
\text { evil eyes. The twigs have } \\
\text { significant place in crimination } \\
\text { as well. Kids use the seeds as } \\
\text { bullet for their toy gun. }\end{array}$ \\
\hline 15 & $\begin{array}{l}\text { Punica } \\
\text { granatum L. }\end{array}$ & Daaru & Punicaceae & Shrub & Apr-Sep. & $\begin{array}{l}\text { Eaten Ripened. Are a source of } \\
\text { "Anardana" which is used to } \\
\text { make Chutney. Considered } \\
\text { highly digestive, used to cure } \\
\text { indigestion, stomachache. } \\
\text { "Anardana" is sold at high } \\
\text { price in the market being a } \\
\text { NTFP of high economic } \\
\text { importance. Plant has a high } \\
\text { ritualistic aspect. After } \\
\text { marriage, newlywed couples } \\
\text { worship this tree as an } \\
\text { important ritual. }\end{array}$ \\
\hline 16 & $\begin{array}{l}\text { Pyrus communis } \\
\text { L. }\end{array}$ & Nashpati & Rosaceae & Tree & Mar- Sep. & $\begin{array}{l}\text { Eaten Raw. The semi ripened } \\
\text { fruits are cooked as vegetable. } \\
\text { Ripened fruits are processed as } \\
\text { Jams and Chutneys. } \\
\text { Considered rich in fiber and } \\
\text { anti oxidants, this fruit is } \\
\text { considered good for digestion } \\
\text { and relieves constipation. } \\
\text { Fruits are sold in the local } \\
\text { market at good prices, thus } \\
\text { being a source of income. }\end{array}$ \\
\hline 17 & $\begin{array}{lr}\text { Pyrus } & \text { pashia } \\
\text { Buch.- } & \text { Ham.ex } \\
\text { D.Don } & \end{array}$ & Kainth & Rosaceae & Tree & April-June & $\begin{array}{l}\text { Eaten ripened. Very effective } \\
\text { in curing oral ulcers. Twig } \\
\text { used as "Daatun". Wood is a } \\
\text { good source of fuelwood. }\end{array}$ \\
\hline 18 & $\begin{array}{l}\text { Rubus ellipticus } \\
\text { Smith. }\end{array}$ & Aakhe & Rosaceae & Shrub & $\begin{array}{l}\text { March- } \\
\text { May }\end{array}$ & $\begin{array}{l}\text { Eaten Ripened. Considered } \\
\text { digestive. Used for fencing. }\end{array}$ \\
\hline 19 & $\begin{array}{l}\text { Terminalia } \\
\text { bellirica }\end{array}$ & Baheda & Combretaceae & Tree & April- Dec & $\begin{array}{l}\text { Eaten raw, consumed in } \\
\text { powdered form. Digestive, }\end{array}$ \\
\hline
\end{tabular}




\begin{tabular}{|l|l|l|l|l|l|l|}
\hline & (Gaertn.) Roxb. & & & & $\begin{array}{l}\text { cures "Tridosha", immunity } \\
\text { booster, } \\
\text { constituent } \\
\text { ofriphala". }\end{array}$ \\
\hline 20 & $\begin{array}{l}\text { Terminalia } \\
\text { chebula } \text { Retz. }\end{array}$ & Harad & Combretaceae & Tree & April- Jan & $\begin{array}{l}\text { Eaten raw, consumed in } \\
\text { powdered form. Digestive, } \\
\text { cures "Tridosha", immunity } \\
\text { booster, constituent of } \\
\text { "Triphala". }\end{array}$ \\
\hline
\end{tabular}

Most of ripe fruits are consumed raw except Cordia dichotoma, Ficus palmate, Pyrus communis which are cooked as vegetable. Fruits of Aegle marmelos, Morus alba and Pyrus communis are processed and consumed as Jam. Juice of the fruit of Aegle marmelos is also sold in the market at good prices. Fruits of Juglans regia and Punica granatum (Anardana) are dried and being sold at high prices thus playing major role in the upliftment of the rural people. Fresh fruits of Cordia dichotoma, Ficus palmate, Myrica esculenta, Pyrus communis, Phyllanthus emblica, Terminalia bellerica, T. chebula are collected from the wild by the rural people and sold in the local market, thus have good commercial value.

Roots of Berberis aristata have commercial significance. Tender for uprooting of the roots is being issued by Himachal Pradesh Forest Department from time to time for its trade in the market. The roots are used in the treatment of eye disorder by the trade name of "Rasaunt" (Chauhan, 1999).

Leaves of Cordia dichotoma, Ficus auriculata, F.hispidum, F. palmate, Morus alba, Myrica esculenta are used as fodder for cattle and believed to increase the milk yield.

The wild edible fruit spp. recorded in the present study have medicinal significance as well. Most of the reported species are used to treat indigestion and constipation which include Aegle marmelos, Ficus palmate, Morus alba, Myrica esculenta, Pyrus communis, Phyllanthus emblica, Terminalia bellerica, T.chebula; latter three being the constituent of "Triphala", one of the best cure for digestion related problems. Twig of Juglans regia is used as "Daatun" and used to cure tooth decay and toothache. Fruit of Morus alba, Myrica esculenta and Phyllanthus emblica are rich in anti oxidants and very good immunity boosters. Seeds of Prinsepia utilis is expressed and used as the massage oil to relieve muscular pains.

Many of these plants have socio ritualistic aspect thus being integral part of the life style of the folklore. Leaves of Aegle marmelos are offered to Lord Shiva especially on Mahashivratri. Twigs bearing fruit of Phyllanthus emblica is used as altar during "Tulsi Vivah" (Sharma et al, 2020). Twigs of Prinsepia utilis have role in warding off the evil and in crimination; seed oil used in Tantra Mantra. The plant of Punica granatum is worshipped by newlywed couple. Just as the seeds are enclosed in a rind, the newlywed couple should also keep the family united.

\section{Conclusion:-}

The outcome shows that a large portion of natural products are gathered by folklore along with other activities like cultivating, visiting woodlands for fuel wood and fodder or during the grazing of their live stocks. The finding of this paper gives first hand information on accessibility and utilization of wild natural products. Wild fruits together with their products can be used to ensure food security and their availability round the year. Wild fruits can make out the best supplement for nutrition. As they already play an important role in uplifting rural economy, but proper marketing strategies should be there for proper commercialization of these wild resources. During last few decades, the forests are receding away and so many of these wild fruits as well. So proper documentation of their availability and utilization is important for their propagation and conservation strategies. These underutilized and neglected Himalayan resources should be best utilized for food, nutritional and livelihood security. In addition to the processing of these wild fruits into Jams, Pickles, Juices, we need to take them to next level- Neutraceuticals and Functional foods. In the Global market place, the Neutraceuticals and Functional Foods have become a multibillion dollar Industry, United States and Japan being the largest markets in the World for Neutraceutical Products (Keservani,2010). India known for its Ayurvedic supermacy and a vast reservoir of wild resources has a wide scope in this growing Industry. Inter-disciplinary collaborations can take this Industry to new heights. 


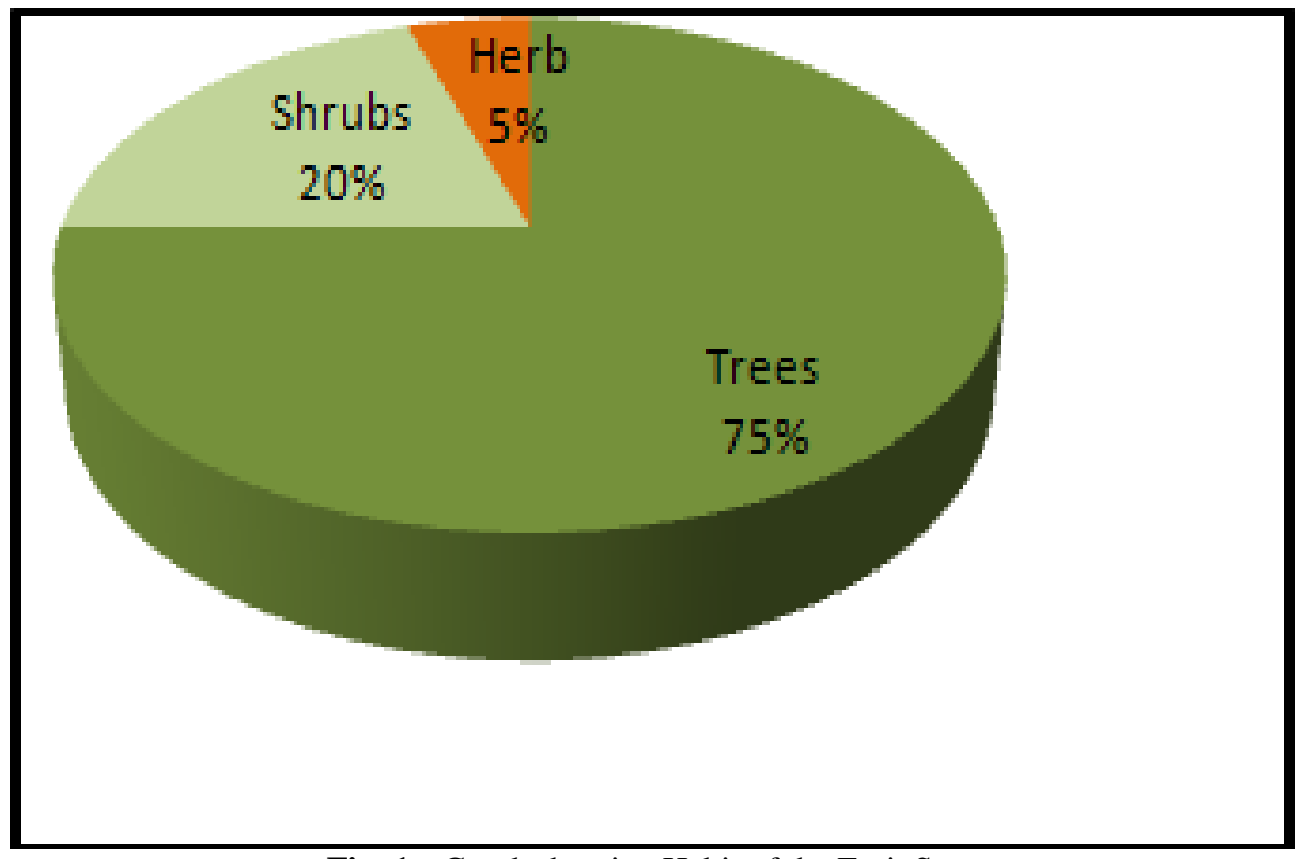

Fig. 1:- Graph showing Habit of the Fruit Spp.

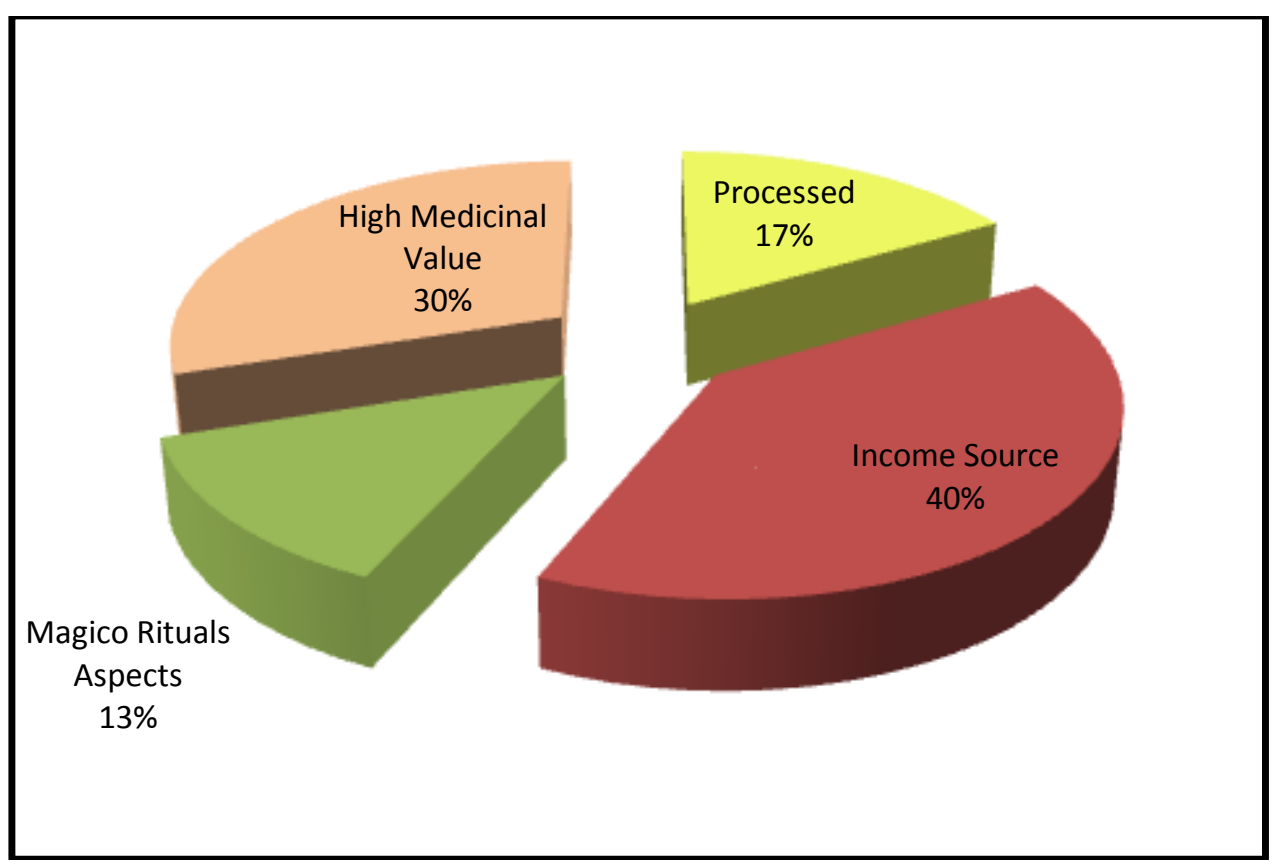

Fig. 2:- Graph showing Utilization Aspect of Spp. 

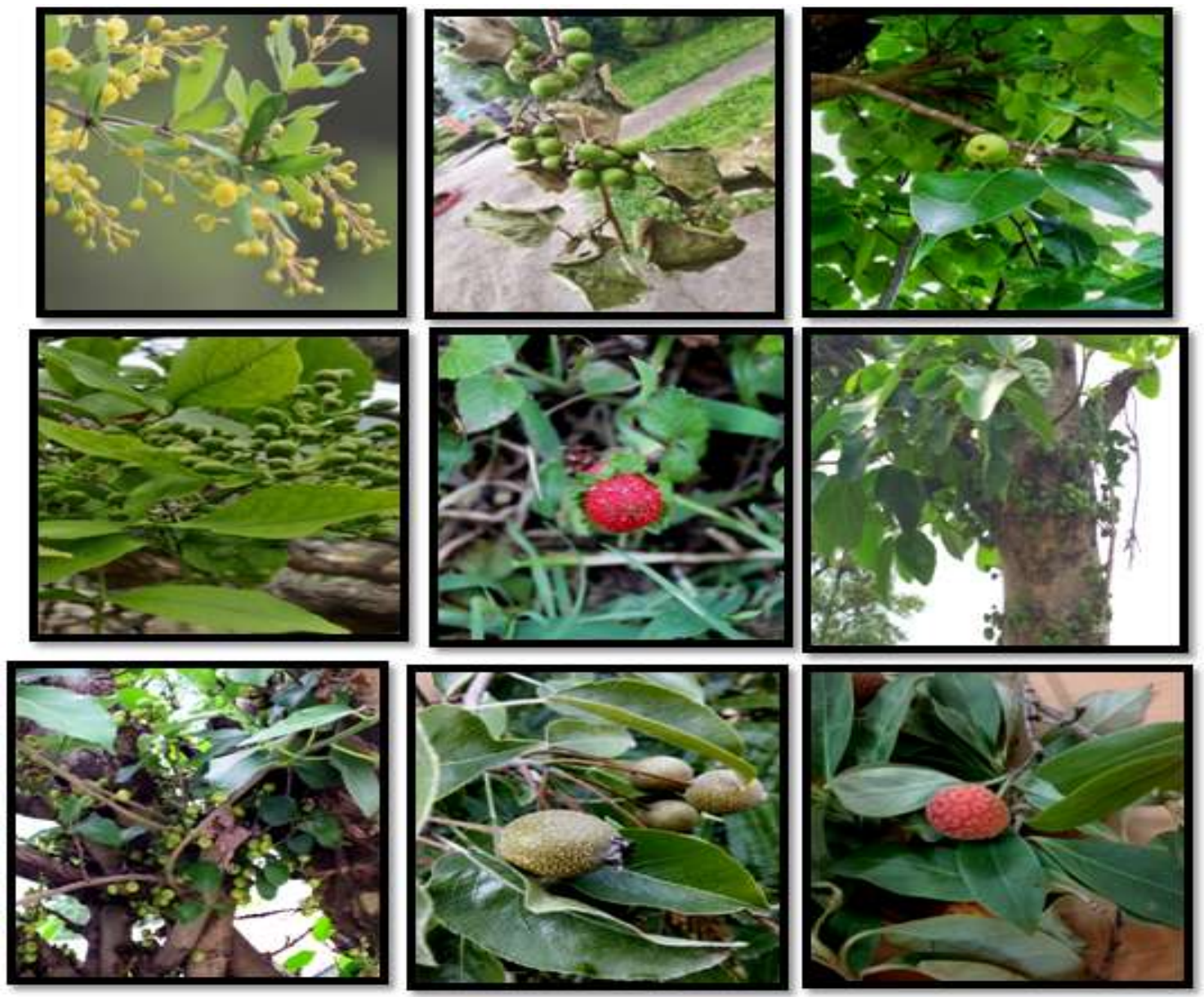

1. Berberis aristata DC.

2. Cordia dichotoma G.Forst

3. Pyrus communis L.

4. Aegle marmelos (L.) Correa

5. Duschesnea indica (Andr.) Focke

6. Ficus auriculata Lour.

7. Ficus hispida L.f.

8. Pyrus pashia Buch.- Ham.ex D.Don

9. Cornus capitata Wall.

\section{Conclusion:-}

Authors are grateful to the natives of Mandi District for sparing their valuable time and sharing the valuable information regarding wild edible fruits and their traditional utilizations.

\section{Reference:-}

1. Arya D. Major wild fruits used by locals of Garhwal Himalaya. International Journal of Advanced Life Sciences. 2013; 6(3):145-149.

2. Boktapa N.\& Sharma A. K. (2010). Wild medicinal plants used by local communities of Manali, Himachal Pradesh, India. Ethnobot Leaf. 14: 259-267.

3. Brij,Vats S. K., Singh R. D., Gupta A. K. (1996). Plants used as ethnomedicine and supplementary food by Gaddis of Himachal Pradesh, India. Ethnobotany in human welfare Edited by: Jain. Deep publications, New Delhi. pp. 383-387.

4. Census of India (2011). District Census Mandi- Village and Town wise Primary Census Abstract. Series 3. Part XII B. Directorate of Census Operation. 
5. Chauhan N.S. (1999). Medicinal and aromatic plants of Himachal Pradesh. Indus Publishing Company, New Delhi.

6. Chowdhery H. J. \& Wadhwa B. M. (1984). Flora of Himachal Pradesh: An analysis, Department of Environment, Government of India, Botanical Survey of India, Howrah, India. Vol. 1-3: pp. 860.

7. Collett H. (1902). Flora Simlensis: A Handbook of the flowering plants of Simla and the neighbourhood. Thacker, Spink \& co., London, 2nd edition by Thacker, Spink and Co., Calcutta and Simla. Reprint; Bishen Singh Mahendra Pal Singh, Dehradun, India. pp. 652.

8. Gaur, R. D., \& Singh, P. B. (1995). Ethno-medicinal plants of Mandi district. Himachal Pradesh, BMEBR, 14(1), 1-11

9. Gour RD. Wild edible fruits of Garhwal Hills. The Himalaya 1977; 1:66-70

10. Jain S. K. \& Rao R. R. (1976).A handbook of field and herbarium methods. Today and tomorrow printers and publishers, New Delhi.

11. Jain, S. K. (2010). Manual of ethnobotany. Scientific publishers.

12. Kala CP. Prioritization of cultivated and wild edible by local people in the Uttaranchal Hills of Indian Himalaya. IJTK. 2007; 6(1):239-244.

13. Kanchan U, Tewari LM, Pangtey YPS, Jalal JS. Diversity and Distribution of wild Edible Fruits Plants of Uttarakhand. Biodiversity Potentials of the Himalaya (eds. LM Tewari, YPS Pangtey and Geeta Tewari), 2010; 157- 196.

14. Kaur I., Sharma S., Lal S. (2011). Ethnobotanical survey of Medicinal plants used for Different diseases in Mandi district, Himachal Pradesh. International Journal of research of Pharmacy and Chemistry. 1(4).

15. Keservani, R. K., Kesharwani, R. K., Vyas, N., Jain, S., Raghuvanshi, R., \& Sharma, A. K. (2010). Nutraceutical and functional food as future food: a review. Der Pharmacia Lettre, 2(1), 106-116.

16. Kumar S., Raj H., Sharma J. (2013). Ethnobotanical explorations in the Balh valley region of North Western Himalaya. Methodology. 2(7).

17. Martin GJ. (1995) Ethnobotany: A methods manual. Chapman and Hall, London

18. Samant, S. S., \& Dhar, U. (1997). Diversity, endemism and economic potential of wild edible plants of Indian Himalaya. The International Journal of Sustainable Development \& World Ecology, 4(3), 179-191.

19. Satyarthi K. (2018). Wild Edible Fruits of Himachal Pradesh. Himachal Pradesh State Biodiversity Board, Shimla.

20. Sharma P., Agnihotry A., Sharma P. P., Sharma L. (2013).Wild edibles of Murari Devi and surrounding areas in Mandi district of Himachal Pradesh, India. International Journal of Biodiversity and Conservation 5.9:592-604.

21. Sharma R, Seth MK. (2020). Role of Rural Women in Consrvation of Plant Resources and its Management in District Mandi, Himachal Pradesh. International Journal of Creative Research Thoughts. ISSN:2320-2882, Volume.8, Issue 5, pp.1493-1501, May 2020. 